\title{
CONCENTRATION OF TRACE METALS IN THE BLOOD OF CHILDREN
}

\author{
H. T. DELVES, BARBARA E. CLAYTON AND JOAN BICKNELL \\ Institute of Child Health, University of London, Hospital for Sick Children, Great Ormond Street and \\ Botleys Park Hospital, Chertsey, Surrey
}

Tipton (1960), Butt et al. (1964), and Stitch (1957) have shown that 20 trace metals are consistently present in human tissues although only seven of these are known to be essential to man. In addition to the ingestion of trace metals from food, materials such as paints, plastics, and rubbers, which contain many metals, may be mouthed and chewed by children. Excessive ingestion of lead is a well-known health hazard for children, particularly for those who have pica (Greenberg et al., 1958; Bicknell, Clayton, and Delves, 1968), and is associated with increased concentrations of lead in blood.

The purpose of the present study was to establish 'normal' values for a series of metals in the blood of children, and to determine whether they were altered in children in whom the physician was considering a possible diagnosis of lead poisoning, since so many materials contain a mixture of metals.

The choice of the metals to be investigated in our study was determined by the available analytical techniques. Spark-source mass spectrometry permits determination of all the metals of interest (Table I)

TABLE I

TRACE METALS CONSISTENTLY PRESENT IN HUMAN TISSUES AND THEIR POSSIBLE SOURCES FOR CHILDREN WITH PICA

\begin{tabular}{|c|c|c|c|c|c|}
\hline \multirow[b]{2}{*}{ Metal } & & \multicolumn{4}{|c|}{ Possible Source* } \\
\hline & & Paints & $\begin{array}{l}\text { Plastics or } \\
\text { Rubbers }\end{array}$ & $\begin{array}{l}\text { Paper and } \\
\text { Printing } \\
\text { Inks }\end{array}$ & $\begin{array}{l}\text { Oils and } \\
\text { Greases }\end{array}$ \\
\hline $\begin{array}{l}\text { Aluminium } \\
\text { Barium .. } \\
\text { Bismuth .. } \\
\text { Cadium . . } \\
\text { Chromium } \\
\text { Cobalt .. } \\
\text { Copper . . } \\
\text { Gold .. } \\
\text { Iron .. } \\
\text { Lead . } \\
\text { Manganese } \\
\text { Molybdenum } \\
\text { Nickel . } \\
\text { Rubidium } \\
\text { Silver . . } \\
\text { Strontium } \\
\text { Tin } \\
\text { Titanium . . } \\
\text { Vanadium } \\
\text { Zinc . . }\end{array}$ & 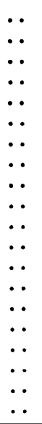 & $\begin{array}{l}+ \\
+ \\
+ \\
+ \\
+\end{array}$ & $\begin{array}{l}+ \\
+ \\
+ \\
+\end{array}$ & $\begin{array}{l}+ \\
+ \\
+ \\
+ \\
+ \\
+\end{array}$ & $\begin{array}{l}+ \\
+\end{array}$ \\
\hline
\end{tabular}

- Browning (1961) in the small samples of blood $(2-5 \mathrm{ml})$ available from the children, but this method is prohibitively expensive. The alternative use of atomic absorption spectroscopy provides a relatively cheap method capable of determining most of the metals of interest, i.e., iron, copper, zinc, cobalt, nickel, manganese, bismuth, lithium, strontium, cadmium, lead, and chromium.

A preliminary report on part of this work was presented to the International Symposium on Environmental Health Aspects of Lead, 2-6 October 1972 in Amsterdam.

\section{Patients ANd Methods}

\section{Control Children}

Fifty-one boys and 31 girls aged 4 days to 15 years were inpatients at the Hospital for Sick Children and a further four boys and five girls aged 18 months to 13 years were inpatients at Poole Hospital. The ages for this group followed a normal distribution pattern (Fig. 1). The blood samples

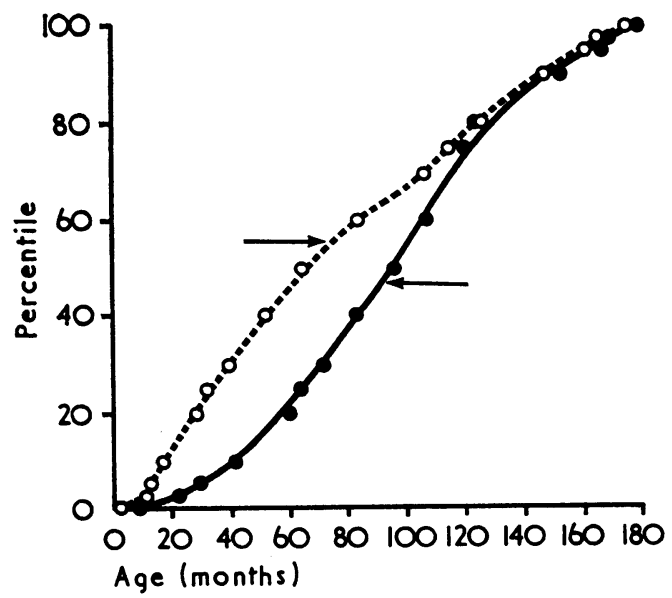

Fig. 1. Age distribution for the two groups of children:

- - control group; 0 -.- o patients; arrows indicate mean values. 
were obtained when venepuncture was being performed for other purposes, in many cases while the child was anaesthetized. Control children had a wide variety of disorders, but children with the following features were excluded: mental retardation, an $x$-ray involving use of a contrast medium during the previous year, congenital heart disease, leukaemia or bleeding disorder, or convulsions. Excessive pica was not mentioned in the history of any of these children.

\section{Patients}

Blood samples were sent to the laboratory from 128 boys and 61 girls aged 2 months to 15 years. Although this age range was the same as that for the control children, a higher proportion of patients were in the 3 to 6 years range (Fig. 1). Seventeen of the patients had more than one blood sample taken for analysis. The interval between taking samples from the same patient ranged from a few days to two years. Most of the patients were under the care of the Hospital for Sick Children, Great Ormond Street, Queen Mary's Hospital, Carshalton, and Poole General Hospital, Dorset, but 16 were at different hospitals. The main clinical features leading to the laboratory request for a lead estimation were severe pica, usually associated with mental retardation, anaemia, convulsions or abdominal pain.

\section{COLLeCtion OF SAMPLES}

Whole blood was collected by venepuncture into disposable plastic syringes using $0.1 \mathrm{ml}$ of heparin solution (sodium or lithium salt) as anticoagulant. The samples were sent to the laboratory (by post when necessary) either in the syringe with the needle covered, or after transfer to Staynes* heparin tubes. Specimens were stored at $-9^{\circ} \mathrm{C}$ in the laboratory prior to analysis. As certain preparations of heparin may contain manganese, the analysis of blood samples was restricted to those which had been collected into heparint known to be relatively free from manganese and other trace metals, i.e., concentrations of $1,000 \mathrm{iu} / \mathrm{ml}$ and $5,000 \mathrm{iu} / \mathrm{ml}$, but not higher concentrations. A detailed account of trace metal contamination from heparin has been reported (Delves, 1970).

\section{Chemical Analysis}

Duplicate $2 \mathrm{ml}$ portions of the blood samples were oxidized with nitric, perchloric, and sulphuric

*Staynes Laboratories Ltd., Marlow, Bucks.

†Supplied by Paines \& Byrne Ltd., Greenford, Middlesex, Evans Medical Supplies Ltd., Liverpool, Weddel Pharmaceutical Co. Ltd., London, and Boots Pure Drug Co., Nottingham. acids, and the residues were dissolved in $2 \mathrm{~N}$ hydrochloric acid. Eleven metals were determined in $1 \mathrm{ml}$ portions of the hydrochloric acid solutions by a procedure involving sequential solvent extraction and atomic absorption (Delves, Shepherd, and Vintner, 1971). Chromium was determined directly in the aqueous hydrochloric acid solutions of the oxidized blood samples, also by atomic absorption spectrophotometry.

\section{Mathematical Analysis of Results}

Of the 12 metals investigated only iron, copper, and lead concentrations in blood were normally distributed in the control group of children. Zinc concentrations in the blood of these children tended to follow a log normal distribution but the remaining metals fitted neither a log normal nor a normal distribution. Three mathematical techniques were employed to establish the upper and lower concentration limits for the 12 metals in the control children. Percentile points were established by computer calculation for zinc, iron, lead, nickel, chromium, and bismuth. A censored distribution analysis (Cohen, 1957) was used to establish the concentration limits for manganese, strontium, cadmium, lithium, and cobalt. The concentrations of copper in blood were dependent upon age and it was, therefore, necessary to calculate the limits for this metal from the standard deviation about the regression line for concentration with age. The lower and upper concentration limits for the control group were the 2.5 and 97.5 percentile points for those metals for which a significantly large $(P<0.01)$ number of abnormal results were observed in the patient group, and the 1 percentile and 99 percentile points in all other cases. In this way the number of abnormal values that would be observed due to chance fluctuations in sampling were minimized.

\section{RESULTS}

Figures 2 to 13 show the percentile points for the metal concentrations in blood for both groups of children. The mean values for each group are arrowed. These cumulative distribution plots show clearly the difference between the two groups of children. Iron, copper, and lead (Fig. 2, 3, and 6) are normally distributed for the control group of children and a comparison of these symmetrical

\section{LEGENDS TO FIGURES}

FIG. 2 to 7 and 8 to 13. Cumulative distributions of the concentrations of metals in the blood of children:

- - o patients; $-\bullet$ controls; arrows indicate mean values. 

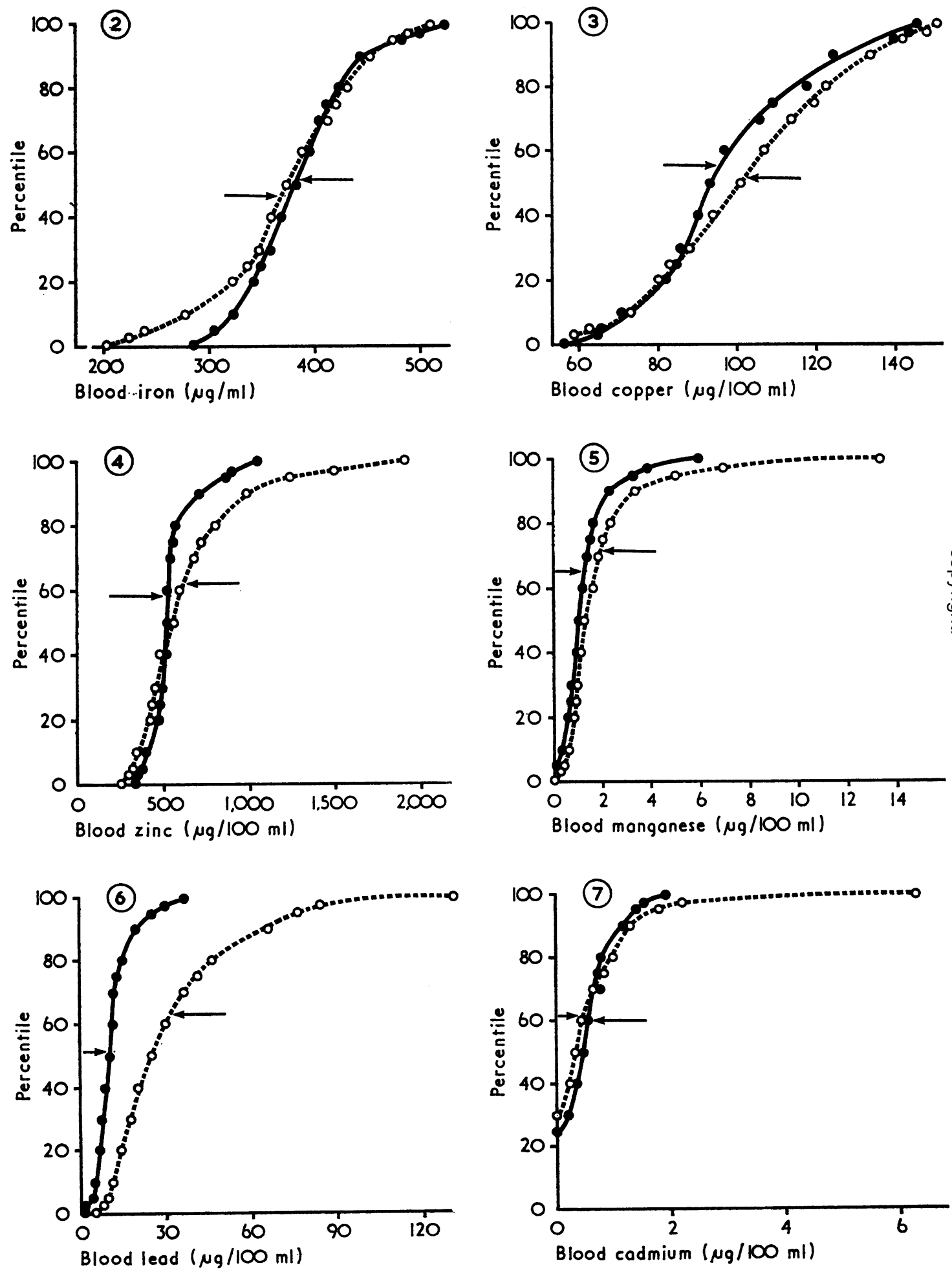

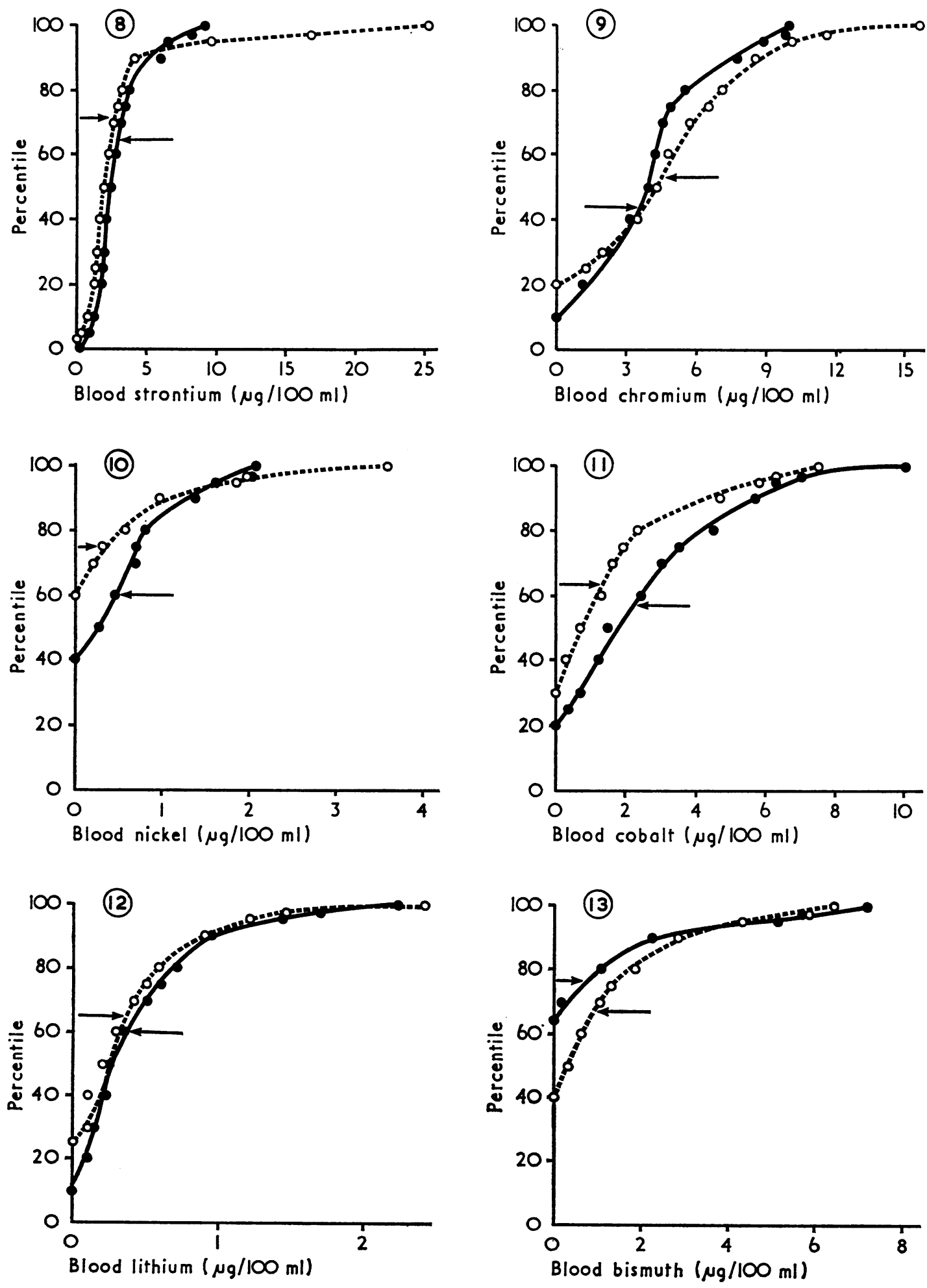
TABLE II

CONCENTRATION OF 12 METALS IN THE BLOOD OF CHILDREN

\begin{tabular}{|c|c|c|c|c|c|c|c|c|}
\hline & & & \multicolumn{3}{|c|}{ Control Group of Children } & \multicolumn{3}{|c|}{ Patients } \\
\hline \multicolumn{3}{|c|}{ Metal } & $\underset{\text { Mean }}{\text { Concentration }}$ & $\begin{array}{c}\text { Observed } \\
\text { Range }\end{array}$ & $\begin{array}{l}\text { No. of } \\
\text { Tests }\end{array}$ & $\stackrel{\text { Mean }}{\text { Concentration }}$ & $\begin{array}{c}\text { Observed } \\
\text { Range }\end{array}$ & $\begin{array}{c}\text { No. of } \\
\text { Tests }\end{array}$ \\
\hline $\begin{array}{l}\text { Iron .. } \\
\text { Zinc .. } \\
\text { Copper .. } \\
\text { Lead .. } \\
\text { Manganese } \\
\text { Cadmium } \\
\text { Strontium } \\
\text { Chromium } \\
\text { Cobalt .. } \\
\text { Nickel .. } \\
\text { Lithium. . } \\
\text { Bismuth }\end{array}$ & $\begin{array}{l}\ldots \\
\ldots \\
\ldots \\
\ldots \\
\cdots \\
\ldots \\
\ldots \\
\ldots\end{array}$ & 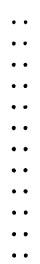 & $\begin{array}{c}386 \cdot 0 \\
510.0 \\
97.9 \\
11.7 \\
1 \cdot 2 \\
0.49 \\
2 \cdot 8 \\
3 \cdot 5 \\
0.46 \\
2 \cdot 3 \\
0.38 \\
0.67\end{array}$ & $\begin{array}{c}290-525 \\
319-1040 \\
55-147 \\
1-32 \\
0-5 \cdot 7 \\
0-1.9 \\
0-8 \cdot 9 \\
0-9 \cdot 7 \\
0-2 \cdot 1 \\
0-9.3 \\
0-2 \cdot 1 \\
0-6.5\end{array}$ & $\begin{array}{l}91 \\
84 \\
84 \\
44 \\
90 \\
89 \\
77 \\
50 \\
67 \\
69 \\
69 \\
48\end{array}$ & $\begin{array}{c}373 \cdot 4 \\
617 \cdot 9 \\
102 \cdot 2 \\
32 \cdot 3 \\
1 \cdot 8 \\
0.57 \\
3 \cdot 0 \\
4 \cdot 1 \\
0.32 \\
1 \cdot 37 \\
0.36 \\
0.93\end{array}$ & $\begin{array}{c}200-520 \\
210-2284 \\
44-162 \\
1-140 \\
0-15 \cdot 0 \\
0-7 \cdot 9 \\
0-27 \cdot 4 \\
0-15 \cdot 0 \\
0-5 \cdot 0 \\
0-8 \cdot 4 \\
0-3 \cdot 0 \\
0-6 \cdot 5\end{array}$ & $\begin{array}{r}206 \\
192 \\
183 \\
203 \\
206 \\
204 \\
182 \\
85 \\
167 \\
167 \\
146 \\
131\end{array}$ \\
\hline
\end{tabular}

Concentrations are $\mu \mathrm{g} / 100 \mathrm{ml}$ for all metals except iron, in which the units are $\mu \mathrm{g} / \mathrm{ml}$.

curves with those for the other metals illustrates the skewed nature of distribution of the latter.

The mean concentrations and observed ranges for the 12 metals are given, for both groups, in Table II. Because of the limited sample size, and technical difficulties in the earlier stages of the investigation, it was not possible to determine all 12 metals in every sample. Consequently the number of tests shown in
Table II are not the same for each metal that was ? investigated, However, $75 \%$ of the control group 8 had nine or more metals studied and $90 \%$ of patients had nine or more metals studied. Generally, bismuth, chromium, and lithium were not studied in every patient.

The difference between the mean concentrations $\overrightarrow{0}$ of metals in blood for both groups as a whole wers

TABLE III

CONCENTRATION LIMITS FOR 12 METALS IN BLOOD AND NUMBERS OF OBSERVED VALUES OUTSIDE THESE LIMITS

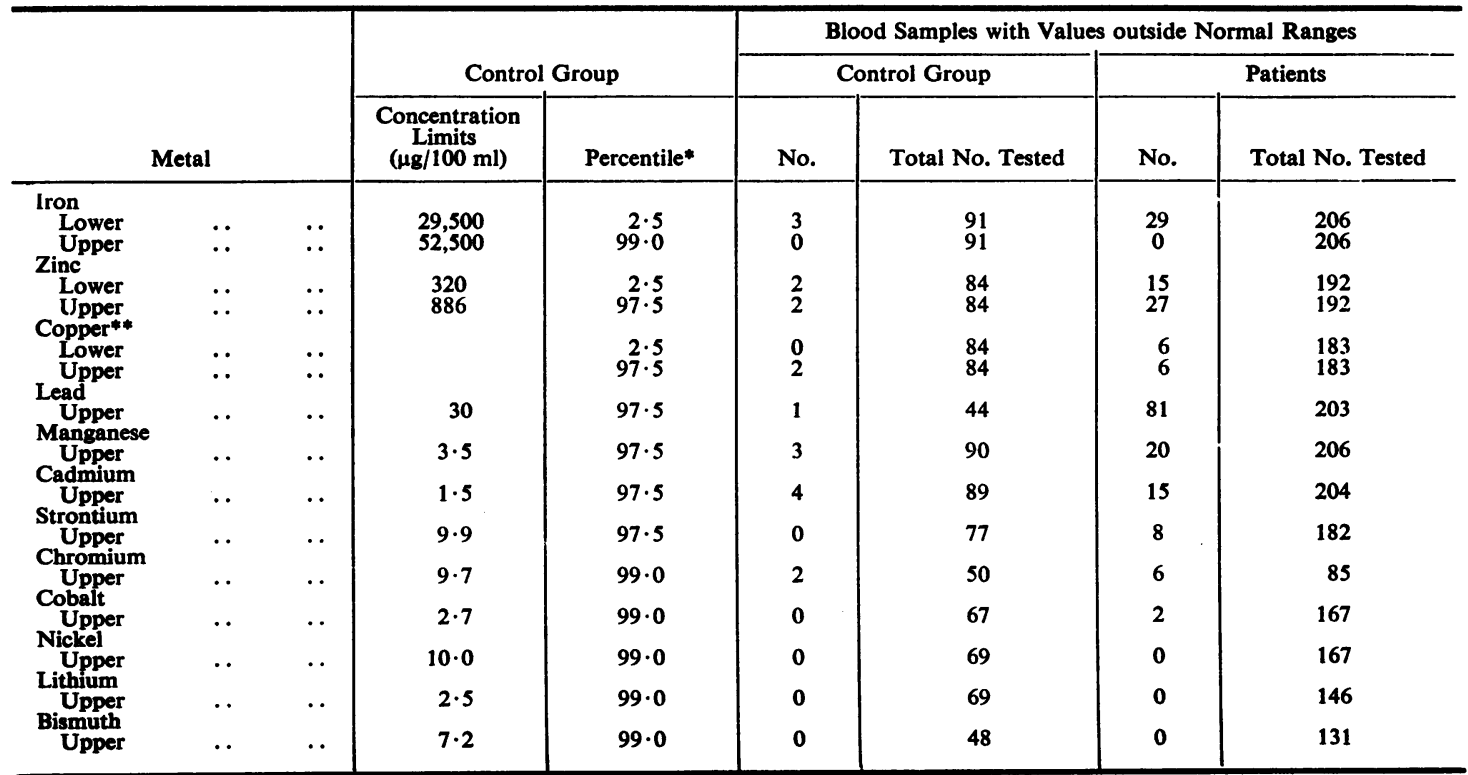

* 2.5 percentile $=97.5 \%$ of control group are above this figure 97.5 percentile $=97.5 \%$ of control group are below this figure

* The concentration of copper in blood varies with age. The range (mean $+2 \mathrm{SD}$ ) for the control group was from $76-158 \mu \mathrm{g} / 100 \mathrm{ml}$ at less than 1 month to $41-124 \mu \mathrm{g} / 100 \mathrm{ml}$. at 15 years. 
significant only for lead, $\mathrm{P}<0.001$, zinc $\mathrm{P}<0.005$, manganese, $P<0.02$, and nickel, $P<0.005$. The mean concentrations were also calculated for the male and female children within each group, but there were no significant differences.

The correlation of concentrations with age was investigated for male and female children within each group. Only copper showed any significant correlation $(P<0.05)$ with age for the control group of children. The copper concentration decreased as the child became older. This negative correlation has been taken into consideration in calculating, for the control group, the upper and lower limits which are given in Table III.

In the patients copper again showed a negative correlation with age and this was also observed for manganese and strontium. Only zinc showed a positive correlation with age, i.e., the blood concentration increased as the child became older.

Table III shows the upper and lower limits of concentrations in blood for the control group of children, with the number of results outside these limits for each group of children. A more detailed analysis of these abnormal values revealed that whereas no children from the control group showed more than one abnormal result, among the patients there were 37 children with two abnormal results, 10 with three abnormal results, 10 with four abnormal results, and two children with five abnormal results. No children had more than five abnormal results.

The interrelationship between any pair of metals studied was investigated for both groups of children within the age ranges $0-36$ months, 37-72 months, and 73-180 months. In the control group there were significant $(P<0.05)$ correlations for seven pairs of metals only, although not for all the age groups. In the patients there were significant correlations for 14 pairs of metals. The data are given in detail in Table IV.
A retrospective study of the case notes of children at the Hospital for Sick Children, Great Ormond Street, Queen Mary's Hospital, Carshalton, and Poole General Hospital was carried out. In half of these patients the lead concentration was raised. As many of them were severely retarded it was impossible to find any consistent clinical patterns which could be related to changes in the concentration of other metals.

\section{Discussion}

The determination of concentrations of metals in blood as a study of metal ingestion by children has the obvious limitation that it comprises only one facet of the total body content and distribution of the metal throughout body tissues. The present study was limited to an investigation of concentrations in blood because samples could be collected easily from large numbers of children without the risk of contamination with metals, which is not the case for the collection of urine samples.

The concentration may change in response to causes other than ingestion of the metal itself. Factors that result in changes include: (1) excessive ingestion of a given metal resulting in an increased blood concentration of that metal, e.g., lead and pica (Bicknell et al., 1968); (2) excessive ingestion of one metal resulting in an increase or decrease in the blood concentration of another metal, e.g., the anaemia that is observed in lead poisoning leads to a reduction in the whole blood iron level; (3) disease states resulting in increases or decreases in concentrations but not in any way related to ingestion of the metals, e.g., the increase in plasma copper and decreases in plasma zinc levels observed in leukaemia (Delves, Alexander, and Lay, 1972) and in other diseases (Fell, Canning, Husain, and Scott, 1972).

Concentrations of 11 metals in addition to lead have been established for a series of control children

TABLE IV

SIGNIFICANT* INTERRELATIONSHIPS BETWEEN PAIRS OF METALS

\begin{tabular}{|c|c|c|c|c|c|c|c|c|}
\hline \multicolumn{3}{|c|}{ Control Group } & \multicolumn{6}{|c|}{ Patients } \\
\hline Metal & $\underset{(y r)}{\text { Age }}$ & Correlation $* *$ & Metal & $\underset{(y r)}{\text { Age Range }}$ & Correlation & Metal & $\underset{(y r)}{\text { Age Range }}$ & Correlation \\
\hline $\begin{array}{l}\text { Cr, Cd } \\
\text { Fe, Cu } \\
\text { Fe, Ni } \\
\text { Fe, Mn } \\
\text { Cd, Co } \\
\text { Co, Sr } \\
\text { Cr, Zn }\end{array}$ & $\begin{array}{l}3-15 \\
6-15 \\
3-15 \\
6-15 \\
6-15 \\
3-6 \\
3-15\end{array}$ & $\begin{array}{l}- \\
\overline{+} \\
+ \\
+ \\
+\end{array}$ & $\begin{array}{l}\mathrm{Cr}, \mathrm{Cu} \\
\mathbf{C r}, \mathrm{Ni} \\
\mathbf{P b}, \mathbf{F e} \\
\mathrm{Fe}, \mathrm{Ni} \\
\mathrm{Fe}, \mathrm{Co} \\
\mathrm{Cd}, \mathrm{Ni} \\
\mathrm{Cd}, \mathrm{Li}\end{array}$ & $\begin{array}{l}3-15 \\
6-15 \\
6-15 \\
6-15 \\
6-15 \\
3-15 \\
6-15\end{array}$ & $\begin{array}{l}= \\
\bar{Z} \\
+ \\
+ \\
+\end{array}$ & $\begin{array}{l}\mathrm{Ni}, \mathrm{Sr} \\
\mathrm{Ni}, \mathbf{L i} \\
\mathrm{Sr}, \mathbf{L i} \\
\mathbf{P b}, \mathbf{M n} \\
\mathbf{P b}, \mathbf{S r} \\
\mathbf{P b}, \mathbf{C r} \\
\mathbf{C o}, \mathbf{N i}\end{array}$ & $\begin{array}{l}3-15 \\
3-6 \\
6-15 \\
3-6 \\
6-15 \\
3-15 \\
6-15\end{array}$ & $\begin{array}{l}+ \\
+ \\
+ \\
+ \\
+ \\
+ \\
+\end{array}$ \\
\hline
\end{tabular}

- $\mathbf{P}<0.05$

* - Las the first metal increases, the second decreases

+ as the first metal increases, the second increases 
who were in hospital and had a wide range of diagnoses. These figures will be of value as additional evidence in studies on the requirement of trace minerals by children receiving synthetic diets (Bentovim et al., 1970) as the composition of such supplements is based on rather sparse facts (Westall, 1963).

Our data also show changes in concentrations of metals in blood in a series of paediatric patients in whom lead poisoning was being considered as a diagnosis, and indeed the most frequently observed abnormal blood concentrations were, as expected, those of lead (Table III). Eighty-one samples from the patients, but only one sample from the control children, had blood lead concentrations greater than $30 \mu \mathrm{g} / \mathrm{ml}$. The highest value observed for the control children was only $32 \mu \mathrm{g} / 100 \mathrm{ml}$ but values of up to $140 \mu \mathrm{g} / 100 \mathrm{ml}$ were observed for the patients. These results agree with earlier findings and confirm the relationship between excessive lead ingestion and pica (Greenberg et al., 1958; Bicknell et al., 1968). Significant correlations were observed between blood lead concentrations and the blood concentrations of iron, chromium, manganese, and strontium (Table IV). A significant negative correlation between lead and iron was observed for patients aged over 6 years but not for younger patients. It is possible that this indicates an increased resistance to lead by the haemopoietic system in the younger child, since children at greatest risk of lead poisoning are aged between 3 and 5 years.

The positive correlations between concentrations of lead and those of chromium, manganese, and strontium suggest a similar relationship between pica and the excessive ingestion of these metals as is the case for lead. It is also possible that these metals may be associated with lead in the materials that are chewed by the children; for example, lead chromate is used in the manufacture of paints and eating such paint would result in the ingestion of both lead and chromium.

The abnormally high levels of cadmium in blood must be a result of excessive ingestion since this metal is not essential and is present in normal body tissues at very low concentrations. The absence of a positive correlation between lead and cadmium is probably due to the much lower concentration range observed for cadmium than for chromium, manganese, and strontium (Table II).

The abnormal concentrations of copper that were observed (six high and six low results from the patients and two raised values from the controls) may be a result of excessive ingestion of other metals. There is a significant negative correlation between chromium and copper for the patients. The negative correlation between iron and copper observed for 8 the control group may be due to the decrease in $\frac{3}{8}$ blood copper with age since for the control boys ? there is a positive correlation between iron and age. $\overrightarrow{\vec{F}}$ The significant negative correlation between iron and lead for the patients would have masked these observations.

The abnormally low concentrations of zinc that were observed for the patients (Table III) may have been due to the ingestion of other metals, but there was no evidence of a correlation between zinc and any $\vec{\circ}$ other metal for the patient group. One might have $\overrightarrow{\vec{\omega}}$ expected a correlation between zinc and cadmium but this was not observed. The high zinc values are $\frac{\curvearrowright}{\infty}$ probably due to some metabolic disturbance since a $\stackrel{\rho}{\rightarrow}$ positive correlation between lead and zinc, which would have implicated pica, was not observed.

It is difficult to explain the negative correlation that was observed between nickel and iron for both groups of children. There were no abnormally high values for nickel for either group of children, ruling out pica.

Though a retrospective examination of the case notes of children with abnormal concentrations of metals indicated no obvious relationship between out results and the clinical data, our study did show that of the 12 metals chosen for investigation, sevenlead, zinc, copper, manganese, strontium, cadmium, and chromium-were present at abnormally high concentrations in the blood of some children with suspected lead poisoning (many of whom had pica) and that iron, zinc, and copper were present sometimes at abnormally low concentrations. Retrospective examination of case notes has obvious limitations and the assessment was further complicated by the high incidence of mental retardation and excessive ingestion of lead. Our observations suggest that more detailed studies of these metals should be performed prospectively in a group of children without a history of subnormality but with pica, and that the study should include metabolic balances.

\section{SUMMARY}

Samples of whole blood taken from a control $\tilde{O}$ group of children and from a group of children $\underset{\mathrm{W}}{N}$ suspected of having lead poisoning have been analysed, by atomic absorption spectroscopy, for 12 metals-lead, copper, zinc, cadmium, manganese, strontium, chromium, iron, bismuth, lithium, nickel, $\stackrel{\oplus}{+}$ and cobalt. The main clinical features leading to the 0 laboratory request for a blood lead estimation were $\stackrel{0}{0}$ severe pica, usually associated with mental retardation, anaemia, convulsions or abdominal pain. $\stackrel{\mathbb{Q}}{\varrho}$ 
Many samples from the patients contained significantly high concentrations, relative to the control group, of the first seven metals listed, whereas other samples from the patients contained significantly low concentrations of iron, copper, and zinc. It was not possible to find any consistent clinical patterns which could be related to these changes.

We thank Mrs. P. Edwards and Miss G. Shepherd for technical assistance with the analyses of the samples and Mr. L. Friedman and Dr. B. Carter for help with the statistical analysis.

Financial assistance from the Wellcome Trust is gratefully acknowledged.

\section{REFERENCES}

Bentovim, A., Clayton, B. E., Francis, D.E.M., SHEPHERD, J., and WolfF, O.H. (1970). Use of an amino acid mixture in treatment of phenylketonuria. Arch. Dis. Childh., 45, 640.

Bicknell, J., Clayton, B. E., and Delves, H. T. (1968). Lead in mentally retarded children. J. ment. Defic. Res., 12, 282.

BrownING, E. (1961). Toxicity of Industrial Metals. Butterworth's Scientific Publications, London.

Butt, E. M., Nusbaum, R. E., Gilmour, T. C., Didio, S. L., and Mariano, Sister (1964). Trace metal levels in human serum and blood. Arch. environm. Hlth, 8, 52.
COHEN, A. C. (1957). Solution of estimating equations for truncated and censored samples from normal populations. Biometrika, 44, 225.

DeLVES, H. T. (1970). Ph.D. thesis, University of London.

-, AleXANDER, F. W., and LAY, H. (1972). Changes in the plasma concentrations of copper and zinc in childhood leukaemia. Brit. J. Haematol. 24, 525.

- SHEPherd, G., and VinTER, P. (1971). The determination of eleven metals in small samples of blood by sequential solvent extraction and atomic-absorption spectrophotometry. Analyst, 96, 260.

Fell, G. S., Canning, E., Husain, S.L., and Scott, R. (1972). Symposium on trace substances in environmental health. University of Missouri, Columbia.

Greenberg, M., Jacobziner, H., McLaughin, M. C., Fuerst, H. T., and Pellitteri, O. (1958). A study of pica in relation to lead poisoning. Pediatrics, 22, 756.

Moncrieff, A. A., Koumides, O. P., Clayton, B.E., Patrick, A., D. ReNWICK, A. G. C. and RoberTs, G. E. (1964). Lead poisoning in children. Arch. Dis. Childh., $39,1$.

Stitch, S. R. (1957). Trace elements in human tissue. I. A semi-quantitative spectographic survey. Biochem. J., 67, 97.

TIPTON, I. H. (1960). The distribution of trace metals in the human body. In: Metal Binding in Medicine, edited by M. J. Seven and L. A. Johnson, pp. 27-42. Lippincott, Philadelphia and Montreal.

WestaLl, R. G. (1963). Dietary treatment of a child with maple syrup urine disease (branded-chain ketoaciduria). Arch. Dis. Childh., 38, 485. 